\title{
Therapeutic follow-up and network intervention as a strategy in psychosocial care
}

\author{
Acompanhamento terapêutico e intervenção em rede como estratégia na atenção psicossocial \\ Acompañamiento terapéutico y la intervención de red como estrategia en la atención psicosocial
}

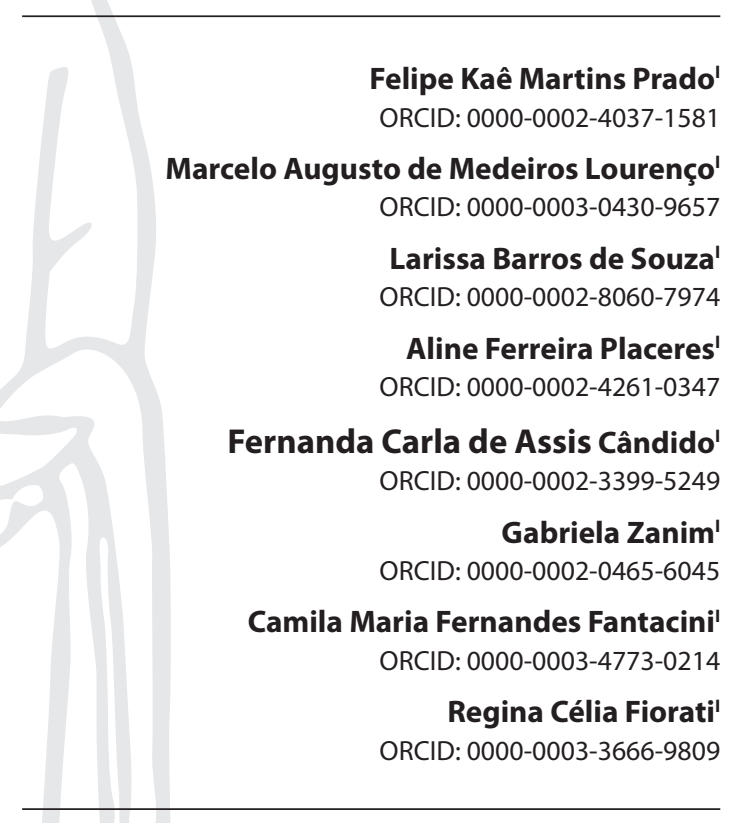

'Universidade de São Paulo. Ribeirão Preto, São Paulo, Brazil.

How to cite this article: Prado FKM, Lourenço MAM, Souza LB, Placeres AF, Candido FCA, Zanim G, et al. Therapeutic follow-up and network intervention as a strategy in psychosocial care. Rev Bras Enferm. 2020;73(1):e20180161. doi: http://dx.doi.org/10.1590/0034-7167-2018-0161

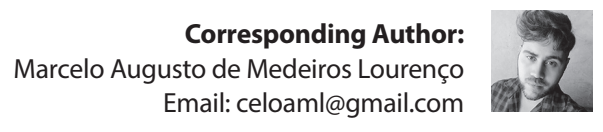

EDITOR IN CHIEF: Antonio José de Almeida Filho ASSOCIATE EDITOR: Fátima Helena Espírito Santo

\begin{abstract}
Objective: to analyze Therapeutic Follow-Up (TF) and Network Intervention (NI) as devices for social network/Psychosocial Care Center (CAPS - Centro de Atenção Psicossocial) user staff construction. Method: an ethnographic study. Data collection instruments were participant observation, field diary, semi-structured interviews and Sluzki's Minimal Map of Relationships. The research site was at a CAPS II of the city of São Paulo. Participants were CAPS user, their family network, professionals and other users. Data analysis took place through Minayo's thematic content analysis framework and Sluzki's personal maps. Results: TF and NI led to greater social participation, autonomy and reorganization of family roles and treatment in CAPS. Conclusion: the TF associated with NI was potent in strengthening the user's personal/ social network and in including them in community activities.

Descriptors: Mental Health; Social Support; Rehabilitation; Personal Autonomy; Ethnography.
\end{abstract}

\section{RESUMO}

Objetivo: analisar o Acompanhamento Terapêutico (AT) e a Intervenção em Rede (IR) como dispositivos para construção da rede social/pessoal de usuário do Centro de Atenção Psicossocial (CAPS). Método: estudo etnográfico. Os instrumentos de coleta de dados foram: observação participante, diário de campo, entrevistas semiestruturadas e Mapa Mínimo das Relações de Sluzki. Local da pesquisa foi em um CAPS II da cidade de São Paulo. Os participantes foram um usuário do CAPS, sua rede familiar, profissionais e outros usuários. Análise dos dados ocorreu através do referencial da Análise de Conteúdo Temático de Minayo e Mapas Pessoais de Sluzki. Resultados: o AT e a IR levaram a maior participação social, autonomia e reorganização dos papéis familiares e tratamento nos CAPS. Conclusão: o AT associado à IR mostrou-se potente no fortalecimento da rede pessoal/social do usuário e na inclusão dos mesmos em atividades comunitárias.

Descritores: Saúde Mental; Reabilitação; Rede Social; Etnografia; Autonomia.

\section{RESUMEN}

Objetivo: analizar el Acompañamiento Terapéutico (AT) y la Intervención en Red (IR) como dispositivos para la construcción de la red social/personal de usuarios del Centro de Atención Psicosocial (CAPS - Centro de Atenção Psicossocial). Método: un estudio etnográfico. Los instrumentos de recolección de datos fueron: observación participante, diario de campo, entrevistas semiestructuradas y Mapa de relaciones mínimas de Sluzki. La ubicación de la investigación fue en un CAPS II de la ciudad de São Paulo. Los participantes fueron usuarios de CAPS, su red familiar, profesionales y otros usuarios. El análisis de datos se realizó a través del marco de análisis de contenido temático de Minayo y los mapas personales de Sluzki. Resultados: el AT y RI llevaron a una mayor participación social, autonomía y reorganización de los roles familiares y el tratamiento en el CAPS. Conclusión el AT asociado con el IR fue potente para fortalecer la red personal/social del usuario y para incluirlos en las actividades de la comunidad.

Descriptores: Salud Mental; Rehabilitación Psiquiatrica; Autonomia; Etnografia; Red Social.

Submission: 05-10-2018 Approval: 07-22-2018 


\section{INTRODUCTION}

From the middle of the twentieth century, conceptions of insanity as an incurable and dangerous illness, and the mentally ill exclusion from society as a form of treatment supported by definitive isolation began to be questioned. Transformation was sought in the way society and science understood insanity and the way of treating it, questioning the physical and symbolic institutionalization of madness in asylums, with deinstitutionalization movements emergence, reformulating ways of treatment and emphasizing treatment centered on community, preferably at the hospital ${ }^{(1-4)}$.

In Brazil, Federal Law 10.216 stands out, representing the possible agreement on mental health care model redirection in the country ${ }^{(5)}$.

Ministerial Ordinances 189/91 and 224/92 of 2000 instituted various types of out-of-hospital services, day hospitals, therapeutic workshops. CAPS (Psychosocial Care Centers - Centros de Atenção Psicossocial) were regulated by Ordinance 336/2004. In late 2011 and early 2012, the Ministry of Health published a series of ordinances that instituted the Psychosocial Care Network in Mental Health (RAPS - Rede de Atenção Psicossocial). RAPS is composed of Primary, Urgent and Emergency, Hospital, Transitional Residential, Strategies of Deinstitutionalization and Psychosocial Rehabilitation (PR) Care, and Strategic Psychosocial Care. This last component encompasses the CAPS in all its modalities ${ }^{(6)}$.

Thus, CAPS start to organize the RAPS and constitute the main community mental health services ${ }^{(7)}$.

Studies show that CAPS have been playing a central role in the deconstruction of the asylum logic that is centered on its performance in the Psychosocial Rehabilitation Strategy. However, there are difficulties in this process of consolidation as services that substitute the hospital-centered logic. It is recommended to carry out outdoors and intersectoral activities for PR promotion and user inclusion. Social ties formation with people and social groups, as well as spaces outside the CAPS walls have been pointed out as a fundamental strategy for the service to fulfill its role $e^{(8-10)}$.

Two intervention strategies have proved to be powerful for effective occupation of social spaces by people under psychological distress and for the construction and/or strengthening of their social networks: Therapeutic Follow-Up (TF) and Network Intervention ( $\mathrm{NI})^{(11-12)}$.

Therefore, the theoretical and methodological framework of this study is TF, which consists of a therapeutic modality that allows the encounter between therapist and patient outside the clinic and its traditional spaces. It can occur at home, in a movie theater, square, park, family gathering, in community activities, among others ${ }^{(13)}$. In this setting, TF is an important device for the inclusion of follow-up in social relations and in society, generating access to public environments and services, and becoming a meeting between subjectivity, collectivity, and the social world(14).

$\mathrm{NI}$ is characterized by meetings held between the central person, his primary social network and a coordinating team. The primary social network of an individual is composed of the closest relations that he owns, and this nature is more affective than formal. Such bonds are, in general, more stable and tend to remain over time, so it is in these relationships that people anchor their lives ${ }^{(15)}$. In this perspective, the NI method consists in carrying out several meetings between user and his social network, aiming at strengthening it and establishing steady nodes that tie the fabric of its social support network. The meetings are designed to build common goals and interests among participants in order to strengthen links between them and to form an active network ${ }^{(16)}$.

$\mathrm{TF}$ and $\mathrm{NI}$ are presented together as powerful strategies to intervene directly in the process of constructing a meaningful social network of a person.

\section{OBJECTIVE}

This study aims to analyze Therapeutic Follow-Up (TF) and Network Intervention (NI) as devices for social network/Psychosocial Care Center (CAPS - Centro de Atenção Psicossocial) user staff construction.

\section{METHOD}

\section{Ethical aspects}

The data presented constitute a dissertation developed in the Graduate Program in Psychiatric Nursing of Escola de Enfermagem de Ribeirão Preto of Universidade de São Paulo, whose project was approved by its Research Ethics Committee. The research is in compliance with Resolution 466/12, following the ethical precepts of autonomy, non-maleficence, beneficence, justice and privacy.

\section{Type of study}

This is an ethnographic study, which brings the researcher immersion results into the everyday, material and symbolic reality of the subjects studied. This was a study developed in the research group and central research participant's natural environment ${ }^{(17-18)}$.

As data collection tools, systematic and participant observation, field diary, Sluzki's Minimal Map of Relationships ${ }^{(19)}$ and semi-structured interviews were used ${ }^{(20-21)}$.

\section{Methodological procedures}

In addition to participant observation and field diary, Sluzki's Minimum Map of Relationships ${ }^{(19)}$ was used to map and analyze the personal social network of the study's central participant and semi-structured interviews with members of the central participant's social network.

Thus, two maps were performed, one at the beginning and one after TF and NI sessions. Sluzki's Network Map allows us to identify people who are part of a person's network of relationships. It is understood the connection between people and each member of their network, what role each member plays and the role that the network as a whole fulfills in their lives ${ }^{(19)}$. Figure 1 presents Sluzki's Minimal Map of Relationships model.

Interviews were used to collect impressions of people identified as members of the central participant's social and personal network, seeking to unveil the history and context that went through the discursive content, relating meanings in their speeches. 


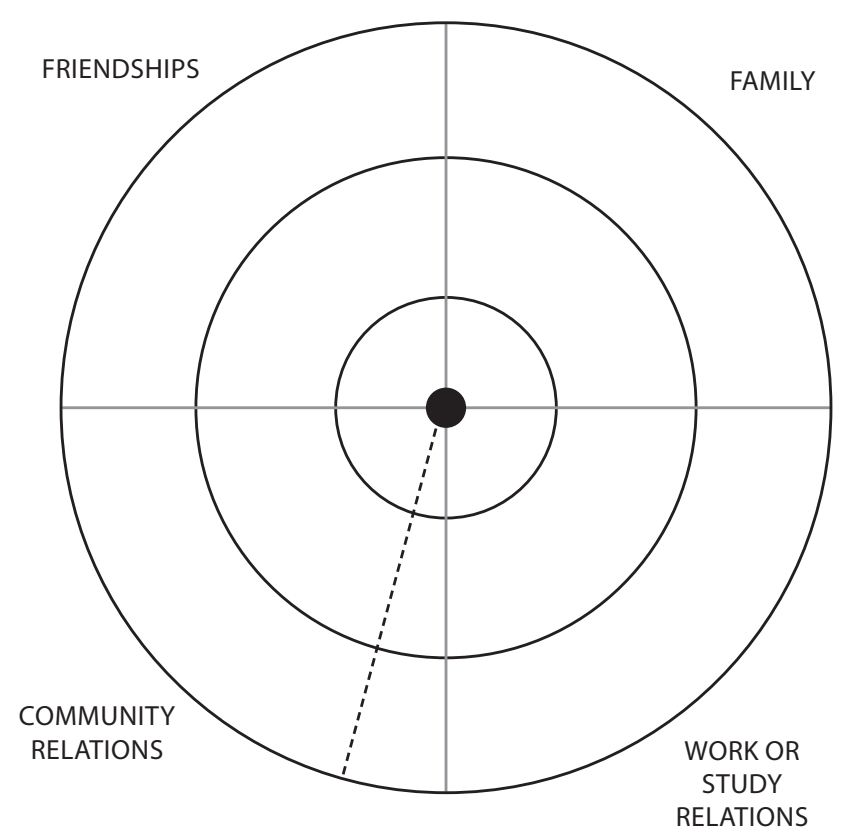

HEALTH AND SOCIAL AGENCY RELATIONS

Note: the Map can be systematized in 4 (four) quadrants: 1 - family: 2 -friendship; 3 - work or school relations; 4 - community, service or creed relations. Three circles of these quadrants are inscribed: internal (closest to the central point, the intermediary represents the individual being mapped), which will contain the most intimate relationships; intermediary, which will contain relations with a lower degree of commitment; external relations, which will cover the most occasional relationships.

Figure 1 - Sluzki's Minimal Map of Relationships, Ribeirão Preto, São Paulo, Brazil, 2016

\section{Study setting}

The research was carried out in a CAPS II of the city of São Paulo, occurring between January of 2015 and March of 2016. Public spaces of São Paulo were included such as streets, services, collective circulation spaces and domiciliary spaces of the research subject where TF and NI were performed.

CAPS functions as a CAPS II since 9/2005, in two shifts, from 8 a.m. to 6 p.m. CAPS provides outpatient care through spontaneous and referenced demand by other services. It embraces, on average, thirty (30) users per day.

\section{Data source}

The study was intentional and counted on the participation of one (1) CAPS user (the central research participant) and seven (7) people from their social network, among family members, users and CAPS professionals. Furthermore, semi-structured interviews were conducted with three (3) CAPS professionals, one (1) family member and one (1) user.

The study's central participant is linked to intensive care program, according to the following criteria for research inclusion: to be 18 years old or older, to agree to participate in the research, to be a CAPS II user for at least two years, and to go to CAPS two or more times a week. These criteria were found to coincide with the problem related to the study's main issue: difficulty of social, family and community insertion that some CAPS users have been presenting in the country's mental health setting.
Participants who are part of the user's social network have met the following criteria to participate in interviews and network meetings: to agree to participate in the survey; to have a link to the research site and to the central research participant; to be 18 years old or above.

\section{Collection and organization of data}

The data collection of this research was carried out through systematic observation and participant. The data obtained through observation were recorded in field diary.

Participant and systematic observation was carried out during CAPS' daily activities in São Paulo; in its team meetings and in activities developed with users from researcher inclusion in these activities as a member. It was carried out in two hundred and thirty-five (235) hours and occurred between January 2015 and March 2016, being distributed between spaces of coexistence, participation of therapeutic groups, tours with users as CAPS activity, or informal outings and participation in team meetings and service assembly. Observation occurred during the TF performed with the research's central participant and in four NI meetings concerning the personal social network of the research's central participant.

This observation phase allowed to select the study's central subject, with which TF and NI sessions were performed.

TF occurred in thirty-two (32) meetings, totaling one hundred and one (101) hours. Meetings were recorded in a field diary. NI occurred in four (4) meetings lasting one (1) hour each.

Semi-structured interviews were conducted with three (3) service professionals, one (1) person in the family and one (1) CAPS user, who were identified as persons from the central participant's personal social network. The theme axes proposed to participants were: the participant's life history, their relationship with the central participant, presence of the researcher in the service during this period, and, specifically, how to assess TF and NI work as strengthening devices of the central participant's personal social network.

\section{Data analysis}

The data were analyzed according to the ethnography reference that sought to elaborate a dense description of the data contained in field diary referring to participant observation, which occurred in researcher participation in a day of the life of service through its insertion in activities performed with users, during TF carried out with the central participant and meetings that constituted NI.

Moreover, two maps of the central participant's social network were applied. The initial map sought to identify how the participant's personal social network was constituted and the second one sought to analyze whether there was difference in the participant's personal social network after TF and NI.

\section{RESULTS}

The description will be presented initially from the field diary records, which recorded the stories, facts and thoughts recorded 
during data collection. Hence, the moment of collection was the very moment in which one assessed what one was living in the contact with service, central participant and his family.

Rodrigo was selected to be the central participant in the research, and his story shows that he has been attending CAPS since 2009. Since his first crisis, he has already undergone six hospitalization cycles. Rodrigo was born and raised in the city of Praia Grande, and when he became psychically ill, he was adopted by relatives (a family of uncles and their children, Rodrigo's cousins), because it was impossible for the progenitor family to care for him. From that moment on, he moved in with his uncles' family in São Paulo.

In 2011, after the death of the aunt who lived in bed, Rodrigo lost the function of caregiver, an activity that guaranteed him some importance in the family. Since then, his only role in the family environment is being a patient. Authors describe that within families with people with mental disorders, they often lose active roles to remain in passive roles ${ }^{(11,14,22-23)}$.

Furthermore, after this period, the relationship between him and his uncle began to intensify in terms of conflicts. When Rodrigo demonstrates more autonomous behaviors, this causes a certain strangeness in the familiar ones.

Rodrigo was the most frequent CAPS user, his presence was always requiring considerable attention from people, both workers and users. Therefore, it was common for people to feel tired because of this intense daily contact. At the same time, it was perceived that, in these same relations, there was a certain affection, a preoccupation in guarding and taking care of Rodrigo so that there he felt protected.

TF was developed with Rodrigo through various activities and spaces of the city, from which Rodrigo attended a theater group, as well as various cultural activities. TF was pointed out by some participants as positive, relating the work to changes in Rodrigo's behavior, making him feel more independent in his decisions:

He felt independent. [...] You always wanted him to do things on his own, he encouraged, you tried that, and deep down you did it. (I1)

\section{DISCUSSION}

The lived process suggests that AT allowed the construction of a bond of trust, of exchange, of mirroring, and this strengthened Rodrigo, brought to him vitality and attempts to connect to social life. However, TF's work and the behavioral changes in Rodrigo were perceived at times by the family as a threat, which generated resistance and conflicts between them. This is pointed out by authors as a similar process, because TF allows the follow-up recovery of autonomy ${ }^{(12-13,24)}$. In the face of a conflicting relationship with his uncle, who reacted negatively to his nephew's quest for greater autonomy, Rodrigo developed a psychotic crisis. Although the family and the CAPS professionals recognized that the conflict and violence were not the exclusive responsibility of Rodrigo, but also the reactions of the uncle to the new postures that he took before the life, the network saw the psychiatric hospitalization of Rodrigo like solution that moment.

It was not a crisis! So look at the confusion, when the person has a desire, organize for it, because you are producing autonomy, and then people understand it as madness. (I2)
In the period of hospitalization, TF was performed during some hospital visits. After hospital discharge, the network reorganized and it was possible to hold four meetings. It was possible to recover the history of the hospitalization, the senses that led to her, mainly regarding the Rodrigo's unusual behavior and realized how his personal network was dense, cohesive and impermeable in certain aspects. When all network members have a relation among themselves, Sluzki ${ }^{(19)}$ states that it is a network of great density.

The author points to this double potential of a dense network, which at the same time can be effective to mobilize around the person and offer him care, but also creates resistance if the person wants to take a new posture and join new groups. This demonstrates the presence of an affectionate, warm and essential network for the existence of Rodrigo, but with the power to decide on his destiny even without his own consent and even if he is not alone responsible for the occurrence of conflicts ${ }^{(19)}$.

Network meetings showed a critical potential in the face of events, professionals and family members were able to analyze the changes in Rodrigo's behavior with greater tranquility, and to appropriate their limitations and new perspectives to be implemented in the treatment. It was perceived that the reflection that occurred in the meetings was able to provoke dislocations in the own network, changes and construction of new senses on the condition of the psychic suffering on the daily experience while at the same time that it rests conservative resources ${ }^{(16)}$.

In the network meetings held, it was realized that work with family was indispensable and implied acceptance of their roles as suffering people who needed help. Work overload, difficult coexistence with the mentally ill person, and shorter time to invest in health promotion actions contribute to the caregiver's illness, especially in situations of high dependence on the individual receiving care $^{(25)}$. In this sense, it was assumed that the establishment of Rodrigo's social contracts involves the reestablishment of contracts for the whole family ${ }^{(26-27)}$.

Rodrigo's meaningful social network, on the one hand, demonstrates a network with access to resources, being updated on practices in line with PR notions. On the other hand, there is a suggestion of a network that has these resources, but it fits them into a dynamic that leads to the patient's withdrawal and psychiatric hospitalization. Care by CAPS must go through the logic of the service center, developing a care network that serves users in its most different spheres. The staff is the main foundation, and the territory is the space of action. CAPS can be considered a reference center, but not the only care locus ${ }^{(11,28)}$.

There is a need to consolidate the RAPS, in the perspective of PR implementation, in an intersectoral field, besides establishing contractualities of subjects under psychological distress. The subject can live, work and earn decent income and integrate real personal networks and that can guarantee the exercise of their autonomy ${ }^{(29)}$.

It is important to emerge the results from the analysis of the data of the maps that, because they are more specific, flee discreetly from the logic of the ethnographic exposition, but they complement it.

Two network maps were applied with the central research participant. The first map was applied before any intervention, following the indication by the user's team to be the study's central participant. 
The second one was applied after all TF and NI interventions, assessing the participant's personal social network and assessing TF and NI's potential benefits for CAPS users, as can be seen in Figure 2.

\section{First Network Map Relations of Rodrigo}

Network Map Relations Adapted from Sluski (2006)

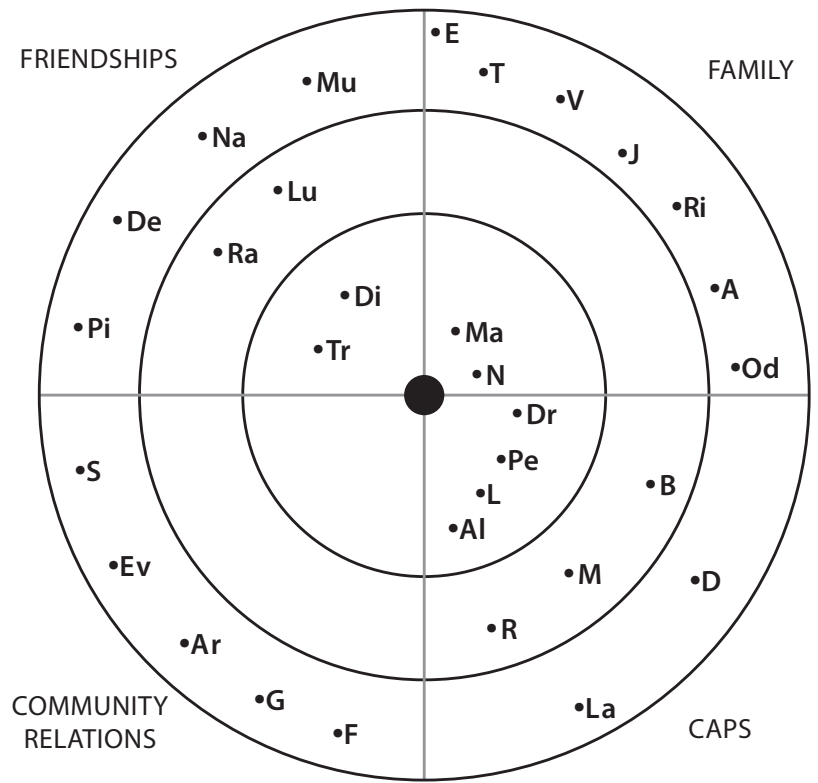

Note: Friendships: 1- Th (thunder), Di (Diego); 2- Lu (Luciano), Mo (Mouse); 3- Mu (Murilo), No (Naldo), De (Denis), Li (Lice); Family: 1-Ma (Maria), N (Natália); T(Tales), A (Augusto), V(Veronica), J (José), Ri (Ricardo), Od (Odvan), E (Edson); Community relationships: 3-S (Soraia - home office in Praia Grande), Ev (husband of S), Ar (Ariana), G (Gisela) and F (Fabiana) daughters of S and EV CAPS: 1- Al (Alvaro), L (Lucio), Pe (researcher), Dr (psychiatrist); 2-R (Renato), M (Marcus), B (Beatriz); 3-The (Larissa), $D$ (Dolores).

Figure 2 - Rodrigo's first meaningful network map, Ribeirão Preto, São Paulo, Brazil, 2016

In the first social map of the study's central participant (Figure 2 ), it can be verified that the relatives mentioned live with the main participant (Tales (uncle), Augusto (Tales' son), Veronica (Tales' daughter), Joseph (Veronica's husband), Ricardo (Veronica's son)). Natália, Tales' wife, died in 2011, is mentioned in several passages, as well as his mother Maria who died the same year. Odvan, his father, is still alive, but does not live with Rodrigo.

Professionals that show up are Álvaro (security), Lúcio (maintenance employee), psychiatrist, Larissa and Dolores (nursing technicians); and still in the CAPS quadrant, the researcher. Beatriz, Marcus and Renato are CAPS users.

In friendships and community relationships quadrants, people mentioned are from the time Rodrigo lived in the city of Praia Grande (Long Beach), with which he no longer had contact. In community relationships, Rodrigo mentioned the maid of the house of his parents, husband and daughters. In friendships, he said the name of eight people, and did not know how to measure how many years ago he has not communicated with them.

Rodrigo's second map (Figure 3), all residents of his home are represented in the first semicircle, except for José who is represented in the third semicircle. Thus, in comparison with the first Map, it can be inferred that subjects of his residence are closer to Rodrigo.

\section{Second Network Map Relations of Rodrigo}

Network Map Relations Adapted from Sluski (2006)

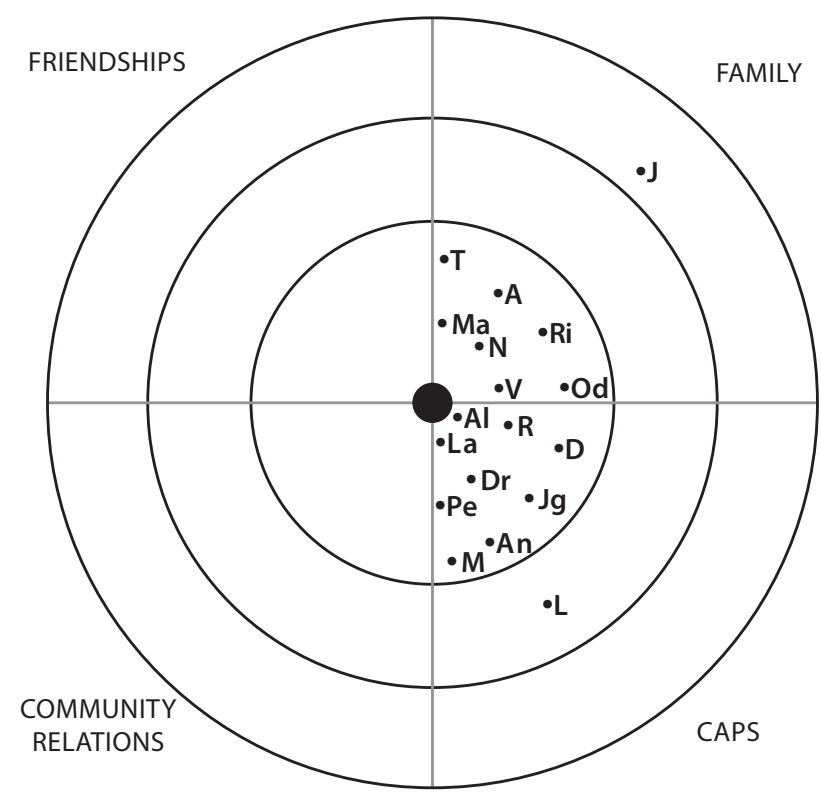

Note: Friendships: blank; Family: 1- Ma (Maria), N (Natália), T (Tales), A (Augusto), V (Verônica), Ri (Ricardo), Od (Odvan); 3- J (José); Community relationshipships: blank; CAPS: 1 - Al (Alvaro - safety), Pe (researcher), Dr (doctor), R (Renato) and M (Marcus), La (Larissa) and D (Dolores) nursing techniques), Jg (Jorge - nurse), An (Angelica - cleaning employee); 2- L (Lucio - maintenance employee.

Figure 3 - Rodrigo's second meaningful network map, Ribeirão Preto, São Paulo, Brazil, 2016

Comparing the first map with the second, the concrete and shared reality dimension is perceived, which imposes itself on the perception of Rodrigo. Although the network portrayed in the first map is more fertile, it is noticed that many people mentioned only existed in virtual dimension in Rodrigo's life, in his memory, perhaps lost inexorably in the past. Although one considers the desirable aspect of a more extensive community network, Rodrigo's personal social network is composed only by family and CAPS professionals.

Social networks favor human development and help fill one's need to relate to others, both in physical and emotional aspects, providing comfort in belonging to a group, being loved and important for maintaining self-esteem ${ }^{(30-31)}$. Friendship and Community relationships quadrants are blank. When asked about their absence, compared to the first map, Rodrigo justified that he has not seen them for a long time. In this sense, it can be inferred that the second map suggests having greater identification with what he lives in the present.

The first map shows that the network is dense, homogeneous, easily accessible, concentrated in two quadrants, with presence in the first semicircle only by people linked to the CAPS (considering only living people). The relatives with whom he lives are all represented in the third semicircle.

The second map maintained quadrant same concentration, but it changed for the most frequent semicircle. Of the eighteen persons cited, sixteen appear in the first semicircle. He brought 
people closer to the CAPS and the people in his family, with the exception of José. Rodrigo's social network, which includes CAPS and the family, is very present in his life. It can be said that Rodrigo's network is present and active in his life, and Rodrigo is present and active in his network's.

\section{FINAL CONSIDERATIONS}

TF caused changes in Rodrigo and in his network, bringing resources to him with gain in autonomy. Rodrigo and his network showed to have many resources and, in this research, many productions were witnessed in these interactions. Rodrigo's network can rethink actions, behaviors and treatment. The strategies used allowed the construction of real and meaningful productions for people involved in the process.

However, it is necessary to create and strengthen community networks for people suffering from psychic suffering, since the study showed that although TF and NI practices have been successful in some aspects, it is still necessary to expand their network to the larger social, community, work insertion, clubs, associations, among others. Thus, the need to strengthen RAPS and its intersectoral strategies emerge.

\section{Study limitations}

The results should be considered in the light of certain limitations. This is a cross-sectional study that used a mental health service user. Although the result was meaningful, it was restricted to a single mental health service in the city, which made it difficult to generalize the results.

\section{Contributions to Nursing, Health, or Public Policy}

This research provided tools to think about strengthening the mental health care user service and good practices that can be performed at CAPS, presenting the importance of mental health public policy in and service based on the psychosocial care that values a citizen subject.

\section{REFERENCES}

1. Amarante P. Loucos pela vida: a trajetória da reforma psiquiátrica no Brasil. Rio de Janeiro: Editora Fiocruz; 1995.

2. Rotelli FA. A instituição inventada. In: Nicácio MFS, organizadora. Desinstitucionalização. São Paulo: Hucitec; 1990. p. 89-100.

3. Guimarães J. Sobre a criação do Hospital Santa Tereza de Ribeirão Preto: outras raízes de uma história [dissertação]. Ribeirão Preto: Universidade São Paulo; 2001. doi: 10.11606/D.22.2001.tde-29012003-104552

4. Birman JA. Cidadania tresloucada: notas introdutórias sobre a cidadania dos doentes mentais. In: Bezerra Junior B, Amarante $P$, editores. Psiquiatria sem hospício: contribuições ao estudo da reforma psiquiátrica. Rio de Janeiro: Relume Dumara; 1992. p. 71-90.

5. Devera, D, Costa-Rosa A. Marcos históricos da reforma psiquiátrica brasileira: transformações na legislação, na ideologia e na praxis [Internet]. Rev Psicol UNESP. 2007 [cited 2017 Jun 06];6(1):60-79. Available from: http://seer.assis.unesp.br/index.php/psicologia/article/ download/1010/932

6. Ministério da Saúde (BR). Portaria n. 3.088, 23 de dezembro de 2011. Dispõe sobre a Rede de Atenção Psicossocial para pessoas com sofrimento ou transtorno mental e com necessidades decorrentes do uso de crack, álcool e outras drogas, no âmbito do Sistema Único de Saúde (SUS) [Internet]. Brasília: Ministério da Saúde; 2011 [cited 2017 Jun 06]. Available from: http://bvsms.saude.gov.br/bvs/saudelegis/ gm/2011/prt3088_23_12_2011_rep.html

7. Pitta A. O que é reabilitação psicossocial no Brasil, hoje? In: Reabilitação psicossocial no Brasil. 2a ed. São Paulo: Hucitec; 2001. p. 19-26.

8. Lima M, Jucá VJS, Santos L. Produção de subjetividade e estratégias de inserção social para usuários em um Centro de Atenção Psicossocial, na Bahia [Internet]. Mental. 2011 [cited 2017 Jun 07];9(16):303-26. Available from: http://pepsic.bvsalud.org/scielo. php?script=sci_arttext\&pid=S1679-44272011000100003\&lng=pt\&tIng=pt

9. Salles MM, Barros S. Inclusão social de pessoas com transtornos mentais: a construção de redes sociais na vida cotidiana. Ciênc Saúde Colet. 2013;18(7):2129-38. doi: 10.1590/S1413-81232013000700028

10. Botelho JV, Lima MV. Perception of the emotions from CAPS II users: an experience report. Fractal, Rev Psicol. 2015;27(2):160-4. doi: $10.1590 / 1984-0292 / 929$

11. Aciole Neto ML, Amarante PDC. O acompanhamento terapêutico como estratégia de cuidado na atenção psicossocial. Psicol Ciênc Prof. 2013;33(4):964-75. doi: 10.1590/S1414-98932013000400014

12. Vasconcelos MFF, Machado DO, Mendonça Filho M. Therapeutic accompaniment and psychiatric reform: issues, tensions and trials of a antimanicomial clinic. Psicol Soc. 2013;25(2):95-107. doi: 10.1590/S0102-71822013000600013

13. Palombini AL. Utópicas cidades de nossas andanças: flânerie e amizade no acompanhamento terapêutico. Fractal, Rev Psicol. 2009;21(2):295-318. doi: 10.1590/S1984-02922009000200008

14. Fiorati RC, Saeki T. As atividades terapêuticas em dois serviços extra-hospitalares de saúde mental: a inserção das ações psicossociais. Cad Ter Ocup UFSCar. 2012;20(2):207-15. doi: 10.4322/cto.2012.022

15. Guadalupe S. Intervenção em Rede e Doença Mental. In.: Anais do Il Encontro De Serviço Social em Saúde Mental: Novas Perspectivas, 2001 Jan 26 [Internet]. Coimbra: Hospital Sobral Cid; 2001 [cited 2017 Jun 07]. Available from: http://www.cpihts.com/PDF03/Sonia\%20 Guadalupe.pdf 
16. More CLO. As redes pessoais significativas como instrumento de intervenção psicológica no contexto comunitário. Paidéia. 2005;15(31):28797. doi: $10.1590 /$ S0103-863X2005000200016

17. Fino CN. FAQs, etnografia e observação participante [Internet]. Rev Eur Etnogr Educ. 2003 [cited 2017 Jun 07];(3):107-17. Available from: https://digituma.uma.pt/handle/10400.13/498

18. Souza MR. Psicologia social e etnografia: histórico e possibilidades de contato. Psicol Ciênc Prof. 2013;35(2):389-405. doi: $10.1590 / 1982-370301742013$

19. Sluzki CE. A rede social na prática sistêmica: alternativas terapêuticas. $3^{a}$ ed. São Paulo: Casa do Psicólogo; 2006.

20. Lapassade G. L'Observation participante. Rev Eur Etnogr Educ. 2001;(1):9-26.

21. Minayo MCS. Qualitative analysis: theory, steps and reliability. Ciênc Saúde Colet. 2012;17(3):621-6. doi: 10.1590/S1413-81232012000300007

22. Alves HMC, Dourado LBR, Côrtes VNQ. A influência dos vínculos organizacionais na consolidação dos Centros de Atenção Psicossociais. Ciênc Saúde Colet. 2013;18(10):2965-75. doi: 10.1590/S1413-81232013001000021

23. Borba LO, Paes MR, Guimarães AN, Labronici LM, Maftum MA. The family and the mental disturbance carrier: dynamics and their family relationship. Rev Esc Enferm USP. 2011;45(2):442-9. doi: 10.1590/S0080-62342011000200020

24. Safra G. Aconpanhamento Terapêutico: uma clínica assentada na ética. ATravessar: Rev Acompan Ter. 2012;1(1):91-8.

25. Oliveira LV, Cirilo LS, Costa GMC. O cuidar do portador de transtorno mental: significado para a família. Rev Baiana Saúde Públ. 2013;37(1):164-78. doi: 10.22278/2318-2660.2013.v37.N1

26. Leão A, Barros S. Inclusão e exclusão social: as representações sociais dos profissionais de saúde mental. Interface (Botucatu). 2011;15(36):137-52. doi: 10.1590/S1414-32832011000100011

27. Santin G, Klafke TE. A família e o cuidado em saúde mental [Internet]. Barbaroi. 2011 [cited 2017 Jun 07];(34):146-60. Available from: http:// pepsic.bvsalud.org/scielo.php?script=sci_abstract\&pid=S0104-65782011000100009\&lng=pt\&nrm=iso

28. Yasui S, Costa-Rosa A. A Estratégia Atenção Psicossocial: desafio na prática dos novos dispositivos de saúde mental [Internet]. Saúde Debate. 2008 [cited 2017 Jun 07];32(78-79-80):27-37. Available from: https://www.redalyc.org/articulo.oa?id=406341773003

29. Lussi IAO, Matsukura TS, Hahn MS. Reabilitação psicossocial: oficinas de geração de renda no contexto da saúde mental. Mundo Saúde. 2010; 34(2):284-90. doi: 10.15343/0104-7809.20102284290

30. Brusamarello T, Guimarães AN, Labronici LM, Mazza VA, Maftum MA. Redes sociais de apoio de pessoas com transtornos mentais e familiares. Texto Contexto Enferm, 2011;20(1):33-40. doi: 10.1590/S0104-07072011000100004

31. Guedes PFM, Souza MCRF. Cartografias de exclusão e inclusão de pessoas com sofrimento mental nos processos de territorialização da Política Nacional de Saúde Mental [Internet]. Estud Pesqui Psicol. 2015 [cited 2017 Jun 07];15(1):40-57. Available from: http://pepsic.bvsalud. org/scielo.php?script=sci_arttext\&pid=S1808-42812015000100004 